\title{
FORMULASI DAN EVALUASI SEDIAAN SABUN CAIR DARI EKSTRAK DAUN JERUK PURUT (Citrus hystrix) DAN KOPI ROBUSTA (Coffea canephora) SERTA UJI CEMARAN MIKROBA
}

\author{
Lilis Rosmainar ${ }^{\mathrm{a}}$ \\ aProdi Kimia, FMIPA, Universitas Palangka Raya \\ *email: lilisrosmainar@mipa.upr.ac.id
}

Received 20 February 2021

Accepted 23 June 2021

\begin{abstract}
Abstrak
Sabun adalah garam natrium atau kalium dari asam lemak yang berasal dari minyak nabati atau hewani. Sabun dapat melindungi kulit dari bakteri. Penambahan bahan alami yang aman bagi kesehatan, dapat memberikan roma yang khas. Ketersediaan bahan alam yang banyak, maka dilakukan penelitian pembuatan sabun cair yang dicampur dengan ekstrak bahan alami. Penelitian ini bertujuan membuat formulasi dan menguji mutu sabun cair ekstrak daun jeruk purut (Citrus hystrix) dan kopi robusta (Coffea canephora). Pengujian mutu sabun cair diharapkan sesuai SNI 06-4085-1996. Pengujian mutu meliputi nilai pH, bobot jenis, viskositas, stabilitas busa, organoleptik dan panelis serta pengujian terhadap cemaran mikroba. Hasil penelitian menunjukkan hasil ekstraksi daun jeruk purut sebesar 37,84\% dan kopi robusta sebesar 51,64\%. Ekstrak ditambahkan ke dalam formulasi sabun cair dengan konsentrasi $2 \%$ dan $4 \%$. Formulasi yang dibuat adalah variasi ekstrak daun jeruk purut $2 \%$ (F1) dan 4\% (F2), serta ekstrak kopi robusta 2\% (F3) dan 4\% (F4). Pengujian mutu sabun cair menunjukkan nilai pH tertinggi 6,8 (F3) dan terendah 6,23 (F2) memenuhi SNI (pH 6-8). Bobot jenis tertinggi 1,05 (F2,F3) dan terendah 1,01 (F1) memenuhi SNI (1,01-1,10). Nilai viskositas tertinggi 2567 cPs (F1) dan terendah 2233 cPs (F4) memenuhi SNI (400-4000 cPs). Stabilitas busa tertinggi $90 \%(\mathrm{~F} 1)$ dan terendah 76,92\% (F4) memenuhi SNI (60-90\%). Uji organoleptik menunjukkan semua formula memenuhi SNI yaitu bentuk cairan homogen, bau khas dan warna khas yaitu hijau $(\mathrm{F} 1, \mathrm{~F} 2)$ dan hitam $(\mathrm{F} 3, \mathrm{~F} 4)$. Uji panelis menunjukkan bahwa rata-rata kesukaan panelis adalah F1 yaitu sabun cair dengan ekstrak daun jeruk purut $2 \%$. Uji cemaran mikroba menunjukkan tidak ada bakteri yang tumbuh (memenuhi SNI). Berdasarkan 4 formula yang telah dibuat maka dapat ditarik kesimpulan bahwa 4 formulasi yang dibuat memenuhi SNI.
\end{abstract}

Kata kunci: Sabun cair, jeruk purut, kopi robusta

\begin{abstract}
Soaps are sodium or potassium salts of fatty acids derived from vegetable or animal oils. Soap can protect the skin from bacteria. The addition of natural ingredients that are safe for health, can give a distinctive aroma. Availability of a lot of natural ingredients, then conducted research on the manufacture of liquid soap mixed with extracts of natural ingredients. This study aims to formulate and test the quality of liquid soap extracts from kaffir lime leaves (Citrus hystrix) and robusta coffee (Coffea canephora). The quality test of liquid soap is expected to comply with SNI 06-40851996. Quality testing includes $\mathrm{pH}$ value, specific gravity, viscosity, foam stability, organoleptic and panelists as well as testing for microbial contamination. The results showed that the extraction of kaffir lime leaves was $37.84 \%$ and robusta coffee was $51.64 \%$. The extract was added to the
\end{abstract}


liquid soap formulation with a concentration of $2 \%$ and $4 \%$. The formulations made are variations of kaffir lime leaf extract 2\% (F1) and 4\% (F2), and robusta coffee extract 2\% (F3) and 4\% (F4). The quality test of liquid soap showed that the highest $\mathrm{pH}$ value was 6.8 (F3) and the lowest was 6.23 (F2) met SNI (pH 6-8). The highest density is 1.05 (F2,F3) and the lowest is 1.01 (F1) meets SNI (1.01-1.10). The highest viscosity value of $2567 \mathrm{cPs}(\mathrm{F} 1)$ and the lowest $2233 \mathrm{cPs}$ (F4) meets SNI (400-4000 cPs). The highest foam stability 90\% (F1) and the lowest $76.92 \%$ (F4) meets SNI (60-90\%). Organoleptic test showed that all formulas met SNI, namely homogeneous liquid form, characteristic odor and distinctive colors, namely green $(\mathrm{F} 1, \mathrm{~F} 2)$ and black $(\mathrm{F} 3, \mathrm{~F} 4)$. The panelist's test showed that the average preference of the panelists was F1, which is liquid soap with $2 \%$ kaffir lime leaf extract. Microbial contamination test showed that no bacteria grew (meets SNI). Based on the 4 formulas that have been made, it can be concluded that the 4 formulations made meet SNI

Keywords: Liquid Soap, kaffir lime, robusta coffee

\section{Pendahuluan}

Sabun merupakan senyawa kimia (Dwinda, 2018) dari garam natrium atau kalium (Jalaluddin, 2019) pada asam lemak yang berasal dari minyak nabati (Syafei,2018) atau lemak hewani (Retnowati, 2013). Sabun dapat berwujud padat atau cair yang dapat membersihkan kulit dari kotoran, minyak dan bakteri. Sabun cair mampu mengemulsikan air, kotoran/minyak. Sabun cair efektif untuk mengangkat kotoran yang menempel pada permukaan kulit baik yang larut air maupun larut lemak dan membersihkan bau pada kulit serta memberikan aroma yang enak dicium (Stefanie et.al 2017).

Sabun dapat dibuat dalam dua jenis yaitu sabun padat dan sabun cair (Wati, 2015). Zat aditif yang paling umum ditambahkan dalam proses pembuatan sabun adalah pewangi, pewarna (Yernisa, 2014), dan garam $(\mathrm{NaCl})$. Pewangi ialah suatu zat bahan bila dicampurkan pada produk sabun seperti sabun wajah (Anjani, 2014) dan sabun badan (Eka, 2016) yang bertujuan untuk menutupi bau yang tidak enak. Jumlah umum yang diperlukan sekitar 0,05\% hingga 2\% untuk campuran sabun. Pewarna digunakan untuk membuat produk agar lebih menarik. $\mathrm{NaCl}$ merupakan sebagai kunci dalam proses membuat sabun dimana bila digunakan dengan banyak akan menghasilkan tekstur sabun yang keras
Sabun cair mempunyai beberapa keunggulan dari pada sabun padat, yang berdasarkan pendapat konsumen bahwa sabun cair lebih higienis, Produk sabun cair lebih menguntungkan, praktis serta ekonomis bagi konsumen dan produksi sabun lebih mudah dang menguntungkan bagi produsen (Hangga 2009).

Bahan-bahan yang digunakan dalam pembuatan sabun semakin bervariasi maka produsen sabun pun berlomba-lomba mencari formula sabun untuk memproduksi sabun yang ekonomis, higienis, tidak membahayakan kesehatan mudah diolah, mudah didapat serta memiliki nilai jual terjangkau (Hangga 2009).

Penambahan bahan alami yang aman bagi kesehatan,sabun cair sendiripun perlu dikembangkan karena dapat memberikan pengaruh positif atau fungsi tertentu terhadap sabun cair yang dihasilkan. Fungsi tersebut antara lain memberikan kesan halus kesan lembut, melembabkan kulit dan memilik aktivitas antibakteri dan memberikan aroma wangi bila di gunakan. Selain itu, dengan penambahan bahan alami tersebut diharapkan dapat memberikan aroma dan sebagai anti bakteri sabun cair yaitu formulasi sabun cair dengan ekstrak kopi dan daun jeruk purut.

Berdasarkan penelitian oleh Yuliani pada tahun 2017 mengatakan bahwa daun jeruk purut memiliki sifat reduksi sehingga 
dapat menghambat dan membunuh bakteri Staphylococcus aureus dan berdasarkan penelitian Praditta Ayu tahun 2017 sabun cair penyanitasi dengan ekstrak ampas Kopi dapat menghambat pertumbuhan bakteri Staphylococcus aureus.

Sehubungan dengan hal diatas, peneliti tertarik untuk membuat formulasi sabun cair dari ekstrak kopi dan daun jeruk purut dengan pengujian uji viskositas, uji $\mathrm{pH}$, uji berat jenis, uji organoleptik, uji panelis dan uji cemara mikroba.

\section{Metode Penelitian}

\section{Desain Penelitian}

Penelitian ini menggunakan penelitian eksperimental sejenis metode yang dilakukan dengan mengadakan kontrol terhadap objek penelitian dan merancang formulasi sabun. Formulasi sabun yang sudah ada dicampurkan dengan ekstrak tumbuhan daun jeruk purut dan kopi robusta dengan pengulangan pengujian 3x. Data dan informasi diambil dari jurnal/artikel, buku dan laporan tugas akhir mahasiswa yang telah dipublikasikan.

\section{Alat dan Bahan}

Alat yang digunakan antara lain gelas ukur $100 \mathrm{ml}$, gelas ukur $50 \mathrm{ml}$ beaker glass $100 \mathrm{ml}$, tabung reaksi $500 \mathrm{ml}$,beaker glass ukur 250, beaker glass $1000 \mathrm{ml}$, sendok, spatale erlemeyer $100 \mathrm{ml}$, kertas saring, timbangan analitik, alat viskositas RION VT$04 F, \mathrm{pH}$ meter, piknometer merk pyrex.

Bahan yang digunakan antara lain ekstrak daun jeruk purut, ekstrak kopi robusta, pelarut etanol $90 \%$, sodium laureth sulfate, TEA-lauryl sulfate, cocamide DEA, cocamidopropyl betaine, sodium chloride, glycerine, citrit acid, DMDM Hydantoin. aqua water, fragrance dan parfum.

\section{Pembuatan Serbuk Simplisia}

Daun jeruk purut diambil dari daerah Cikarang kemudian dikeringkan di bawah sinar matahari selama 3 minggu lalu di blender hingga menjadi serbuk. Kopi robusta diperoleh dari tumbuhan kopi yang tumbuh di daerah lampung dan diolah menjadi serbuk dengan menggunakan ayakan 40 mesh.

\section{Pembuatan Ekstrak}

Pembuatan ekstrak dilakukan dengan metode maserasi yaitu merendam sebanyak 213 gr serbuk simplisia daun jeruk purut (Citrus hystrix) dan kopi robusta (Coffea canephora) ke dalam beaker glass terpisah lalu ditambahkan pelarut etanol 90\% secukupnya, ditutup dengan kertas aluminum foil, lalu didiamkan selama 24 jam dan sesekali diaduk. Setelah 24 jam didiamkan kemudian disaring menggunakan corong yang dilapisi kertas saring sehingga didapat filtrat dan dimasukan kedalam botol coklat. Ampas yang didapat dimaserasi sebanyak 3 kali dengan prosedur yang sama. Filtrat yang diperoleh dipekatkan dengan menggunakan rotary evaporator.

\section{Pembuatan Sabun Cair}

a. Formulasi Sabun

Formulasi sabun yang dibuat dapat dilihat pada tabel 1.

\section{b.Prosedur Pembuatan Sabun}

Menurut pedoman cara pembuatan kosmetik yang baik dan benar tahun 2010 dan penelitian Elok tahun 2017. Proses pembuatan sabun sebagai berikut:

a. Proses I

Mecanpurkan sodium laureth sulfate, cocamide DEA, cocamidopropyl betaine, dan tea laury sulfate kedalam beaker gelas $1000 \mathrm{ml}$ yang berisi air lalu diaduk hingga larut

b. Proses II

Mencampurkan DMDM hydantion, tetrasodium EDTA, dan citric acid ke beaker gelas $250 \mathrm{ml}$ yang terisi air lalu diaduk sampai larut

c. Proses III 
Mencampurkan sodium chloride pada beaker gelas $100 \mathrm{ml}$ yang terisi air lalu diaduk sampai larut

d. Mencampurkan Proses II kedalam Proses I, aduk hingga larut, lalu masukan glycerine lalu diaduk hingga tercampur

e. Memasukkan ekstrak daun jeruk purut/ kopi robusta lalu diaduk sampai tercampur rata

f. Memasukkan fragrance lalu diaduk sampai merata

g. Memasukkan proses III lalu diaduk hingga mengental dan sampai menjadi sabun

Tabel 1. Formulasi sabun

\begin{tabular}{|l|c|c|c|c|}
\hline \multirow{2}{*}{\multicolumn{1}{|c|}{ Bahan }} & \multicolumn{3}{c|}{ Formulasi } \\
\cline { 2 - 5 } & \multicolumn{2}{|c|}{$\begin{array}{c}\text { Daun Jeruk } \\
\text { Purut }\end{array}$} & Kopi Robusta \\
\cline { 2 - 5 } & F1 & F2 & F3 & F4 \\
\hline $\begin{array}{l}\text { Sodium laureth } \\
\text { sulfat }\end{array}$ & $7 \%$ & $7 \%$ & $7 \%$ & $7 \%$ \\
\hline Cocamide DEA & $2,5 \%$ & $2,5 \%$ & $2,5 \%$ & $2,5 \%$ \\
\hline $\begin{array}{l}\text { Cocamidopropyl } \\
\text { betaine }\end{array}$ & $2,5 \%$ & $2,5 \%$ & $2,5 \%$ & $2,5 \%$ \\
\hline $\begin{array}{l}\text { TEA lauryl } \\
\text { sulphate }\end{array}$ & $2,5 \%$ & $2,5 \%$ & $2,5 \%$ & $2,5 \%$ \\
\hline Sodium Chloride & $1,5 \%$ & $1,5 \%$ & $1,5 \%$ & $1,5 \%$ \\
\hline $\begin{array}{l}\text { DMDM } \\
\text { hydantoin }\end{array}$ & $0,1 \%$ & $0,1 \%$ & $0,1 \%$ & $0,1 \%$ \\
\hline $\begin{array}{l}\text { Tetrasodium } \\
\text { EDTA }\end{array}$ & $0,05 \%$ & $0,05 \%$ & $0,05 \%$ & $0,05 \%$ \\
\hline Citric acid & $0,05 \%$ & $0,05 \%$ & $0,05 \%$ & $0,05 \%$ \\
\hline Glyceryl stearate & $1,5 \%$ & $1,5 \%$ & $1,5 \%$ & $1,5 \%$ \\
\hline $\begin{array}{l}\text { Ekstrak kopi } \\
\text { robusta }\end{array}$ & - & - & $2 \%$ & $4 \%$ \\
\hline $\begin{array}{l}\text { Ekstrak daun } \\
\text { jeruk purut }\end{array}$ & $2 \%$ & $4 \%$ & - & - \\
\hline Fragrance & 79,35 & $78,1 \%$ & 79,35 & $78,1 \%$ \\
\hline $\begin{array}{l}\text { Aqua water } \\
\text { Total }\end{array}$ & $100 \%$ & $100 \%$ & $100 \%$ & $100 \%$ \\
\hline
\end{tabular}

\section{Pengujian Mutu Sabun Cair}

Pengujian terhadap mutu sabun mandi cair terbagi 2, yaitu uji fisikokimia sesuai dengan SNI Sabun Mandi Cair 064085-1996 meliputi kadar alkali bebas, nilai $\mathrm{pH}$, uji angka lempeng total, dan bobot jenis. Kedua adalah uji organoleptik terhadap warna, aroma, kekentalan, banyak busa, kesan setelah pemakaian, dan reaksi gatal. Hasil uji mutu dilanjutkan dengan penentuan nilai pembobotan dengan menentukan nilai kepentingan secara subjektif yang diukur perdasarkan penilaian kepentingan (Qisti 2009).

Pengujian dilakukan terhadap sabun seperti nilai $\mathrm{pH}$, bobot jenis, viskositas, stabilitas busa, organoleptik dan panelis.

\section{Hasil dan Pembahasan \\ Pembuatan ekstrak}

Hasil ekstraksi yang diperoleh berupa ekstrak kental dengan rendemen seperti pada tabel 2 di bawah ini:

Tabel 2. Hasil Ekstraksi

\begin{tabular}{|l|l|c|c|}
\hline No & Nama Ekstrak & Total & $\begin{array}{c}\text { Rendemen } \\
(\mathbf{\%})\end{array}$ \\
\hline 1 & Daun Jeruk Purut & $80,62 \mathrm{gr}$ & $37,84 \%$ \\
\hline 2 & Kopi Robusta & $110 \mathrm{gr}$ & $51,64 \%$ \\
\hline
\end{tabular}

Hasil Ekstraksi

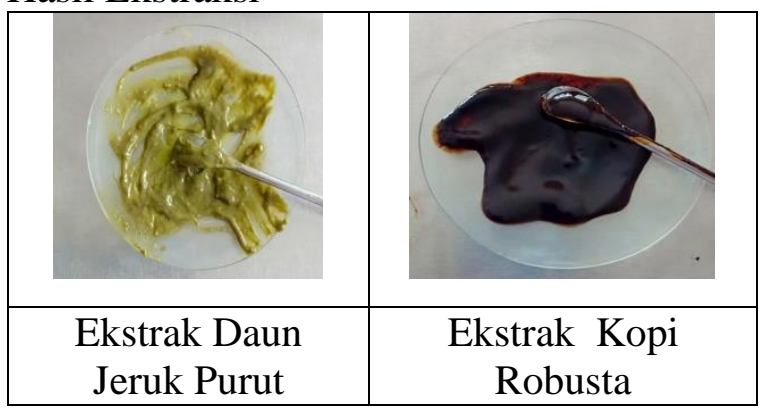

Gambar 1. Ekstak Daun Jeruk Purut dan Kopi Robusta

\section{Pembuatan Sabun}

Sabun cair yang telah dibuat dalam 4 formula memberikan warna dan bentuk sabun dapat dilihat pada gambar 2 di bawah ini: 


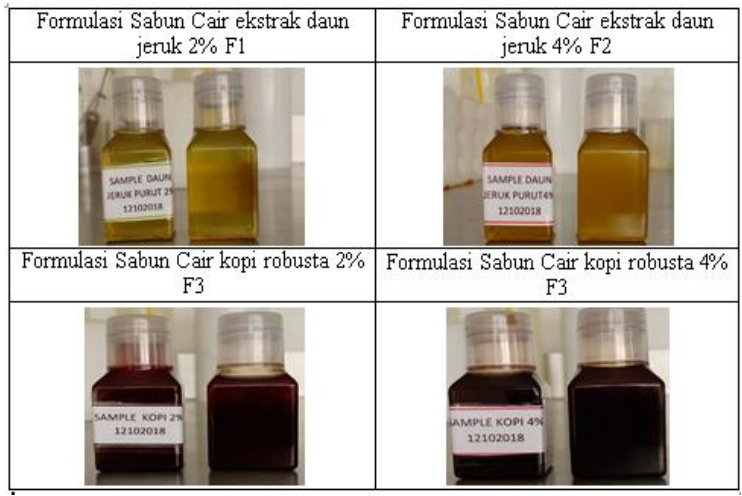

Gambar 2. Produk Sabun Cair

\section{Hasil Pengujian Sabun}

Sabun cair yang telah dibuat, diuji untuk membandingkan kesesuaian mutu sabun cair yang telah dibuat dengan SNI 06-4085-1996 tentang persyaratan mutu sabun mandi cair. Hasil pengujian terhadap mutu sabun dapat dilihat pada Tabel 3 .

Tabel 3. Data Hasil Uji Mutu

\begin{tabular}{|l|c|c|c|c|c|}
\hline \multicolumn{1}{|c|}{ Uji } & F1 & F2 & F3 & F4 & $\begin{array}{c}\text { Stand } \\
\text { ar }\end{array}$ \\
\hline $\begin{array}{l}\text { Viskosita } \\
\text { s (cPs) }\end{array}$ & $\begin{array}{c}256 \\
7\end{array}$ & 2467 & 2667 & 2233 & $\begin{array}{l}400- \\
4000\end{array}$ \\
\hline $\begin{array}{l}\text { Bobot } \\
\text { Jenis }\end{array}$ & 1,01 & 1,05 & 1,05 & 1,03 & $\begin{array}{l}1,01- \\
1,10\end{array}$ \\
\hline pH & 6,47 & 6,23 & 6,8 & 6,53 & $6-11$ \\
\hline $\begin{array}{l}\text { Stabilitas } \\
\text { busa (\%) }\end{array}$ & 91 & 90 & 85,7 & 76,9 & $\begin{array}{l}60- \\
100\end{array}$ \\
\hline $\begin{array}{l}\text { Organole } \\
\text { ptik } \\
\text { (bentuk, } \\
\text { bau, } \\
\text { warna) }\end{array}$ & $\begin{array}{l}\text { Ho } \\
\text { mog } \\
\text { en,k } \\
\text { has, } \\
\text { khas }\end{array}$ & $\begin{array}{l}\text { Homo } \\
\text { gen, } \\
\text { khas, } \\
\text { khas }\end{array}$ & $\begin{array}{l}\text { Homo } \\
\text { gen, } \\
\text { khas, } \\
\text { khas }\end{array}$ & $\begin{array}{l}\text { Homo } \\
\text { gen, } \\
\text { khas, } \\
\text { khas }\end{array}$ & $\begin{array}{l}\text { Homo } \\
\text { gen, } \\
\text { khas, } \\
\text { khas }\end{array}$ \\
\hline $\begin{array}{l}\text { Cemaran } \\
\text { Mikroba } \\
\text { (koloni/gr } \\
\text { am) }\end{array}$ & $\begin{array}{l}\text { Tida } \\
\text { kada } \\
\text { ada }\end{array}$ & $\begin{array}{l}\text { Tidak } \\
\text { ada }\end{array}$ & $\begin{array}{l}\text { Tidak } \\
\text { ada }\end{array}$ & $\begin{array}{l}\text { Tidak } \\
\text { ada }\end{array}$ & $1 \times 10^{5}$ \\
\hline
\end{tabular}

Keterangan:

Data merupakan rata-rata dari tiga kali pengulangan

Berdasarkan tabel di atas, dapat dilihat bahwa 4 formula sabun cair yang telah dibuat memenuhi SNI.

\section{Uji Viskositas}

Pengujian viskositas bertujuan untuk menentukan nilai resistensi zat cair untuk mengalir. Zat cair yang mudah mengalir sangat penting dalam sediaan sabun cair agar memudahkan sediaan apabila sedang digunakan. Makin sedikit kadar air dalam sabun maka viskositas semakin tinggi, dan sebaliknya. Pengujian sabun menggunakan spindel 1 dengan pengukuran untuk kekentanlan 3 sampai $150 \mathrm{dPa}$.

Tabel 4. Hasil Uji Viskositas

\begin{tabular}{|c|l|l|l|l|}
\hline \multirow{2}{*}{$\begin{array}{c}\text { Hari } \\
\text { Ke }\end{array}$} & \multicolumn{4}{|c|}{ Pengamatan Viskositas } \\
\cline { 2 - 5 } H1 & $\begin{array}{l}\text { F2 } \\
2500\end{array}$ & $\begin{array}{l}\text { 253 } \\
\text { cPs }\end{array}$ & $\begin{array}{l}\text { F000 } \\
\text { cPs }\end{array}$ & $\begin{array}{l}\text { F4 } \\
\text { cPs }\end{array}$ \\
\hline H3 & $\begin{array}{l}2500 \\
\text { cPs }\end{array}$ & $\begin{array}{l}2500 \\
\text { cPs }\end{array}$ & $\begin{array}{l}2500 \\
\text { cPs }\end{array}$ & $\begin{array}{l}2600 \\
\text { cPs }\end{array}$ \\
\hline H7 & $\begin{array}{l}2700 \\
\text { cPs }\end{array}$ & $\begin{array}{l}2400 \\
\text { cPs }\end{array}$ & $\begin{array}{l}2500 \\
\text { cPs }\end{array}$ & $\begin{array}{l}2600 \\
\text { cPs }\end{array}$ \\
\hline $\begin{array}{c}\text { Rata- } \\
\text { rata }\end{array}$ & $\begin{array}{l}2567 \\
\text { cPs }\end{array}$ & $\begin{array}{l}2467 \\
\text { cPs }\end{array}$ & $\begin{array}{l}2667 \\
\text { cPs }\end{array}$ & $\begin{array}{l}2233 \\
\text { cPs }\end{array}$ \\
\hline
\end{tabular}

Keterangan :

H1 : Pengujian Viskositas di Hari ke- 1

H3 : Pengujian Viskositas di Hari k-3

H7 : Pengujian Viskositas di Hari ke - 7

F1 : Daun jeruk purut $2 \%$

F2 : Daun jeruk purut $4 \%$

F3 : Kopi robusta $2 \%$

F4 : Kopi robusta $4 \%$

Viskositas berpengaruh terhadap penerimaan dari konsumen. Nilai viskositas yang tinggi akan mengurangi frekuensi tumbukan antara partikel didalam sabun sehingga sediaan lebih stabil (Suryani, 2000). Berdasarkan hasil pengujian viskositas sabun cair dapat dilihat pada gambar 2 menunjukkan F1 dan F3 memiliki nilai viskositas yang tertinggi dengan konsentrasi ekstrak $2 \%$. Hal ini membuktikan bahwa semakin kecil konsentrasi ekstrak yang ditambahkan maka semakin tinggi viskositasnya. 


\section{Uji Bobot Jenis}

Tabel 5. Hasil Uji Bobot Jenis

\begin{tabular}{|c|c|c|c|c|}
\hline $\begin{array}{c}\text { Pengamatan } \\
\text { Bobot jenis } \\
\text { Jenis }\end{array}$ & F1 & F2 & F3 & F4 \\
\hline Piknometer & 1,01 & 1,05 & 1,05 & 1,03 \\
\hline
\end{tabular}

Keterangan:

F1: Daun jeruk purut $2 \%$

F2 : Daun jeruk purut $4 \%$

F3: Kopi robusta $2 \%$

F4: Kopi robusta 4\%

Berdasarkan hasil pemeriksaan bobot jenis yang dilakukan pada tabel 4, semua formula sabun mandi cair daun jeruk purut dan kopi robusta memenuhi Standar Nasional Indonesia untuk sediaan sabun cair, yaitu 1,01-1,10. Pada parameter bobot jenis ini tidak ada perbedaan yang cukup tinggi pada tiap konsentrasi ekstrak yang ditambahkan untuk bahan baku pembuatan bahan cair.

\section{Uji pH}

Uji $\mathrm{pH}$ adalah syarat mutu sabun cair hal itu dikarenakan sabun cair kontak langsung dengan kulit dan dapat menimbulkan masalah apabila $\mathrm{pH}$ tidak sesuian dengan $\mathrm{pH}$ SNI. Menurut SNI pH Sabun cair berkisaran $6-8$. Pengukuran $\mathrm{pH}$ dilakukan 3 hari dengan waktu berbeda hasil pengukuran $\mathrm{pH}$ dapat dilihat pada tabel di bawah ini:

Tabel 6. Hasil Uji pH

\begin{tabular}{|c|c|c|c|c|}
\hline \multirow{2}{*}{ Hari Ke } & \multicolumn{4}{|c|}{ Pengamatan $\mathrm{pH}$} \\
\cline { 2 - 5 } & $\mathrm{F} 1$ & $\mathrm{~F} 2$ & $\mathrm{~F} 3$ & $\mathrm{~F} 4$ \\
\hline H1 & 6,5 & 6,1 & 6,9 & 6,5 \\
\hline H3 & 6,5 & 6,2 & 6,7 & 6,6 \\
\hline H7 & 6,4 & 6,4 & 6,8 & 6,5 \\
\hline $\begin{array}{c}\text { Rata- } \\
\text { rata }\end{array}$ & 6,47 & 6,23 & 6,8 & 6,53 \\
\hline
\end{tabular}

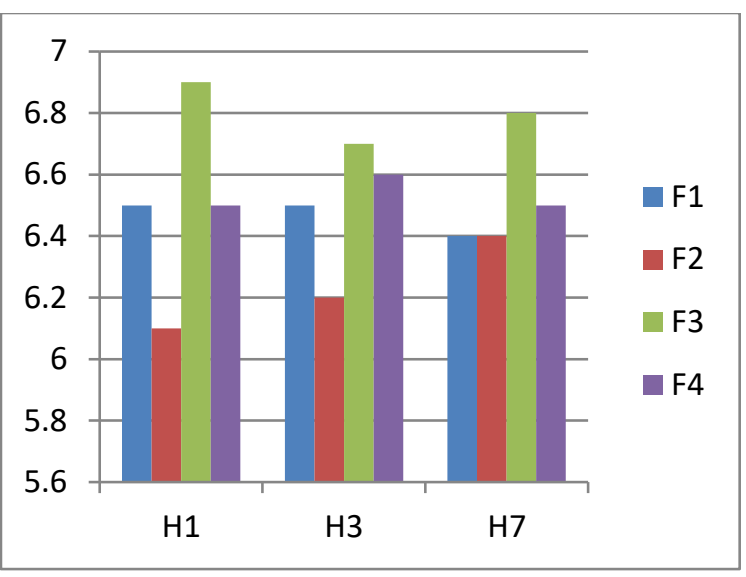

Gambar 3. Grafik Nilai pH Sabun Cair

Keterangan :

$\begin{array}{ll}\text { H1 } & \text { : Pengujian pH di Hari ke- } 1 \\ \text { H3 } & \text { : Pengujian pH di Hari k-3 } \\ \text { H7 } & \text { : Pengujian pH di Hari ke - 7 } \\ \text { F1 } & \text { : Daun jeruk purut } 2 \% \\ \text { F2 } & \text { : Daun jeruk purut 4\% } \\ \text { F3 } & \text { : Kopi robusta } 2 \% \\ \text { F4 } & \text { : Kopi robusta } 4 \%\end{array}$

Dari hasil pengujian $\mathrm{pH}$ yang dilakukan dapat dilihat bahwa sabun cair dengan ekstrak kopi robusta (F3 dan F4) memiliki pH yang lebih tinggi dari F1 dan F2. Hal ini menunjukkan bahwa sabun cair dengan ekstrak kopi memiliki tingkat keasaman yang tinggi, hal ini terjadi karena terdapatnya kandungan asam pada kopi robusta seperti asam klorogenat.

\section{Uji Stabilitas Busa}

Hasil pemeriksaan stabilitas busa dapat dilihat pada tabel di bawah ini:

Tabel 7. Hasil Uji Stabiltas Busa

\begin{tabular}{|c|c|c|c|}
\hline \multirow{2}{*}{ Formulasi } & \multicolumn{3}{|c|}{ Pengukuran Stabilitas Busa } \\
\cline { 2 - 4 } & $\begin{array}{c}\text { Tinggi } \\
\text { Busa awal }\end{array}$ & $\begin{array}{c}\text { Busa } \\
\text { Akhir }\end{array}$ & $\begin{array}{c}\text { Stabilitas } \\
\text { Busa }\end{array}$ \\
\hline F1 & 12 & 11 & $91 \%$ \\
\hline F2 & 10 & 9 & $90 \%$ \\
\hline F3 & 7 & 6 & $85,71 \%$ \\
\hline F4 & 13 & 10 & $76,92 \%$ \\
\hline
\end{tabular}

Salah satu daya tarik sabun adalah kandungan busanya. Stabilitas busa dinyatakan sebagai ketahanan suatu 
gelembung untuk mempertahankan ukuran atau pecahnya lapisan film dari gelembung. Pemeriksaan tinggi busa merupakan salah satu cara untuk mengontrol kestabilan sabun cair dalam menghasilkan busa. Semakin tinggi nilai kestabilan busa, maka semakin tinggi pula kualitas busa yang dihasilkan. Kestabilan busa sangat dipengaruhi oleh suatu ukuran partikel sehingga semakin banyak dan besar ukuran partikel maka kestabilan busa menurun (Asti, 2015).

Apabila busa yang dihasilkan banyak dan stabil maka akan lebih disukai oleh konsumen dibandingkan busa yang sedikit dan tidak stabil. Sabun cair ekstrak daun jeruk purut dan kopi robusta memiliki masing-masing kestabilan busa dengan persentase $60-100 \%$ yang dihitung dari selisih tinggi busa awal dan akhir selama 10 menit. (Widyasanti, 2016).

\section{Uji Organoleptik}

Evaluasi organoleptik dilakukan dengan mengamati secara visual sabun cair meliputi bentuk, warna, dan bau. Pengamatan organoleptik dihasilkan sediaan sabun cair yang berbentuk cairan kental, coklat bening, coklat agak keruh, hitam bening dan hitam dengan aroma khas dari formulasi sabun cair ekstrak daun jeruk purut dan kopi robusta hasil dapat dilihat pada tabel 7 di bawah ini:

Tabel 8. Hasil Uji Organoleptik

\begin{tabular}{|c|c|c|c|c|c|}
\hline \multirow{2}{*}{$\mathrm{N}$} & Para & \multicolumn{2}{|c|}{ Daun Jeruk Purut } & \multicolumn{2}{c|}{ Kopi Robusta } \\
\cline { 3 - 6 } o & $\begin{array}{c}\text { meter } \\
\text { Uji }\end{array}$ & $2 \%$ & $4 \%$ & $2 \%$ & $4 \%$ \\
\hline 1 & Warna & Hijau & Hijau & Hitam & Hitam \\
Bening & Keruh & Mengkilap & Gelap \\
\hline 2 & Bau & Khas & Khas & Khas & Khas \\
\hline 3 & $\begin{array}{c}\text { Bentu } \\
\mathrm{k}\end{array}$ & $\begin{array}{c}\text { Cairan } \\
\text { Homogen }\end{array}$ & $\begin{array}{c}\text { Cairan } \\
\text { Homogen }\end{array}$ & $\begin{array}{c}\text { Cairan } \\
\text { Homogen }\end{array}$ & $\begin{array}{c}\text { Cairan } \\
\text { Homogen }\end{array}$ \\
\hline
\end{tabular}

\section{Pengujian Panelis}

Pengujian tingkat kesukaan panelis terhadap penilaian umum produk sabun cair, Panelis diminta memberikan penilaian akhir terhadap masing-masing sampel yang diuji. Nilai yang tertinggi menandakan bahwa panelis menyukai formulasi sabun cair. Hasil tingkat kesukaan panelis terhadap penilaian umum produk sabun cair dapat lihat pada gambar 5 di bawah ini:

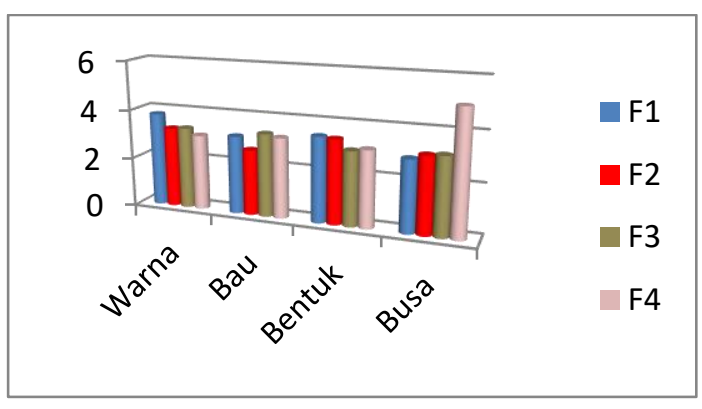

Gambar 3. Grafik Uji Panelis

Keterangan Grafik Uji Panelis

$$
\begin{array}{ll}
1=\text { Sangat tidak suka } & \text { 4. Suka } \\
2=\text { Tidak Suka } & \text { 5. Sangat Suka } \\
3=\text { Biasa } / \text { Netral } &
\end{array}
$$

F1 : Daun jeruk purut $2 \%$

F2 : Daun jeruk purut $4 \%$

F3 : Kopi robusta 2\%

F4 : Kopi robusta $4 \%$

Hasil rata-rata kesukaan 20 panelis menunjukan bahwa warna yang lebih disukai adalah F1. Berdasarkan bau yang lebih disukai adalah F3, berdasarkan bentuk F1 dan formulasi yang memiliki busa yang lebih disukai adalah F4

Tabel 9. Uji Panelis

\begin{tabular}{|l|c|c|c|c|}
\hline \multicolumn{1}{|c|}{ Pengujian } & F1 & F2 & F3 & F4 \\
\hline $\begin{array}{l}\text { Sample yang paling } \\
\text { disukai }\end{array}$ & 8 & 3 & 3 & 6 \\
\hline $\begin{array}{l}\text { Warna yang paling } \\
\text { disukai }\end{array}$ & 6 & 4 & 3 & 7 \\
\hline $\begin{array}{l}\text { Bau yang paling di } \\
\text { sukai }\end{array}$ & 6 & 4 & 3 & 7 \\
\hline $\begin{array}{l}\text { Bentuk yang paling } \\
\text { disukai }\end{array}$ & 9 & 5 & 0 & 3 \\
\hline
\end{tabular}


Sebanyak 20 orang panelis menyatakan bahwa formula F1 lebih disukai daripada F2 dan F3, Warna yang paling disukai adalah $\mathrm{F} 1$ dan yang paling tidak disukai adalah F4. Bau yang paling disukai adalah F4 sedangkan F3 adalah bau yang paling tidak disukai. Bentuk yang disukai adalah F9 dan yang tidak disukai adalah F3.

\section{Pengujian Cemaran Mikroba}

Pengujian cemaran mikroba dilakukan untuk mengetahui aktivitas bakteri di dalam produk pengujian menggunakan bakteri Staphylococcus aureus.

Tabel 10. Uji Cemaran Mikroba

\begin{tabular}{|l|c|c|c|c|}
\hline Parameter & F1 & F2 & F3 & F4 \\
\hline $\begin{array}{c}\text { Staphylococcu } \\
\text { s aureus }\end{array}$ & $\begin{array}{c}\text { Negatif } \\
(-) / g\end{array}$ & $\begin{array}{c}\text { Negatif } \\
(-) / g\end{array}$ & $\begin{array}{c}\text { Negatif } \\
(-) / g\end{array}$ & $\begin{array}{c}\text { Negatif } \\
(-) / g\end{array}$ \\
\hline
\end{tabular}

Keterangan

F1 : Daun jeruk purut $2 \%$

F2 : Daun jeruk purut $4 \%$

F3 : Kopi robusta $2 \%$

F4 : Kopi robusta $4 \%$

Hasil pengujian cemaran mikroba dari 4 formulasi menyatakan tidak adanya bakteri Staphylococcus aureus yang tumbuh. Pengujian dilakukan di Laboratorium Kesehatan Daerah Provinsi DKI Jakarta (Labkesda) Jakarta Pusat. Dan PT. Genero di Kawasan Industri Jababeka II Cikarang.

\section{Kesimpulan}

Penelitian yang telah dilakukan memberikan kesimpulan sebagai berikut:

1. Formulasi sabun cair yang dibuat adalah dengan konsentrasi $2 \%$ dan $4 \%$ untuk masing-masing ekstrak daun jeruk purut dan kopi robusta.

2. Hasil pengujian viskositas yang paling tinggi diperoleh pada F3 sedangkan yang paling rendah pada F4 pada hari ke-1.
3. Hasil bobot jenis diperoleh sekitar 1,01 $-1,05$, pada pengujian $\mathrm{pH}$ diperoleh $\mathrm{F} 3$ yang memiliki $\mathrm{pH}$ yang lebih tinggi dari yang lainnya yaitu 1,05 , pengujian stabilitas busa memiliki konsentrasi 70 - 98\%, dengan konsentrasi yang paling tinggi pada $\mathrm{F} 1$ adalah $91 \%$, sedangkan yang paling rendah pada $\mathrm{F} 4$ adalah $76,92 \%$.

4. Pengujian panelis, diperoleh warna yang disukai F1, bau yang disukai F3, bentuk yang disukai F1, dan busa yang disukai F4. Dengan hasil secara keseluruhan yang disukai oleh panelis adalah sabun cair dengan formulasi F1.

5. Uji cemaran mikroba dari 4 formulasi sabun cair membuktikan hasil pengujian tidak adanya bakteri Staphylococcus aureus yang tumbuh

6. Seluruh formulasi sabun cair yang dibuat memenuhi telah memenuhi SNI..

\section{Daftar Pustaka}

Ade Ferdinan, Rafika Sari, 2017. Pengujian aktivitas anti bakteri sabun cair dari ekstrak kulit dan dain lidah buaya, Fakultas Kedokteran Universitas Tanjung Pura, Pontianak, p. 114.

Anjani, Roso Putri, I. K. E., 2014. Pengaruh Penambahan Sari Aloe Vera Terhadap Sifat Fisik Dan Masa Simpan Sediaan Sabun Transparan.

Eka Syah Putri, W. I. N. D. I., 2016. "Pengaruh Penambahan Ekstrak Kelor Terhadap Kualitasi Sabun Transparan." Jurnal Tata Rias 5.01.Untuk Wajah." Jurnal Tata Rias 3.02 .

BPOM, (2010), Petunjuk Oprasional Pedoman Cara Pembuatan Kosmetik yang Baik, hal 90.

Dwynda, Indra, and Rahadian Zainul. 2018. "Boric Acid (H3 (BO3): Recognize The Molecular Interactions in Solutions." 
Dhavesia, Vika, 2017, Uji aktivitas antibakteri Ekstrak daun jeruk purut (citrus hystrix) terhadap Pseudomonas aeruginosa dan Staphylococcus epidermidis, Yogya Karta, Universitas Atma Jaya Fakultas Bioteknologi Yogyakarta. p. 203.

Fauzi Lubis, M. Rizki, 2018. Pengaruh konsentrasi ekstrak biji kopi robusta (coffeacanephora) terhadap $p H$ saliva dan pertumbuhan bakteri staphyloccus aureus (ATCC® 29213 TM) (In Vitro). Fakultas Dokter gigi Medan, Sumatra Utara, p. 4-10.

Hangga, G. P. D., 2009, Pemanfaatan Kitosan dan Karagenan Pada Produk Sabun Cair, Program Studi Teknologi Hasil Perikanan., Fakultas Perikanan Dan Ilmu Kelautan., Institute Pertanian Bogor.

Istikomah, 2013, Perbandingan metode ektraksi maserasi dan sokletasi terhadap kadar piperin buah cabe jawa (Piperis retrafracti fructus), Universitas Islam Negri Syarif Hidayatullah, Jakarta.

Iswani Tranggono, Retno, Latifah, Fatma, 2008, Buku pegangan ilmu pengetahuan kosmetik, Jakarta, PT. Gramedia.

Jalaluddin, Jalaluddin, Amri Aji, and Sari Nuriani, 2019. "Pemanfaatan Minyak Sereh (Cymbopogon nardus L) sebagai Antioksidan pada Sabun Mandi Padat." Jurnal Teknologi Kimia Unimal 7.1: 52-60.

Marjoni, Mhd.Riza, 2016, Dasar - dasar fitokimia untuk diploma III farmasi, Trans Info Media, Jakarta, Hal 31 46.

Peni Indhrayudha, Septi Sriandita Rahmi, Ratna yuliani, 2011, Aktivitas antibakteri minyak atsiri daun jeruk purut (Citrus Hystrix) terhadap Staphylococcus aureus dan
Escherichia coli, Fakultas farmasi muhammadiyah, Surakarta, p. 50-54.

Peraturan Ka BPOM No. 17, 2014, Persyaratan cemaran mikroba dan logam berat dalam kosmetika, BPOM RI.

Peraturan Ka BPOM No. 18, 2015, Persyaratan teknis bahan kosmetika, BPOM RI.

Peraturan Ka BPOM No.08, (2011), Metode analisis kosmetika, BPOM RI.

Phatalina Naomi, Anna M. Lumban Gaol, M. Yusuf Toha, 2013, Pembuatan sabun lunak dari minyak goreng bekas ditinjau dari kinetika reaksi kimia, Fakultas Teknik Kimia Universitas Sriwijaya, Palembang, p.208

Raymond C Rowe,Paul J Sheikey and Marian E Quin, 2009. Hand book of cosmeceutictical expients and their safeties, Pharmaceutical Press and American Pharmacists Association, Hal 120.

Retnowati, Diah S., Andri C. Kumoro, and Catarina S. Budiyati. 2013. Pembuatan dan Karakterisasi Sabun Susu dengan Proses Dingin.. Jurnal Rekayasa Proses 7.2 : 45-50

Standar Nasional Indonesia, SNI No. 3532:2016, (2016), tentang Sabun Mandi, Badan Standarisasi Nasional, Jakarta.

Syafei, N., Hidayat, D., Emilliano, E. and Men, L. 2018. "Analysis Cracking Corrosion on Carbon Steel Pipes API 5L-X65 In Solution $7700 \mathrm{ml}$ Aquades, $250 \mathrm{ml}$ Acetic Acid and 50 $\mathrm{ml}$ Ammonia with Gas $\mathrm{CO} 2$ and $\mathrm{H} 2 \mathrm{~S}$ in Saturation Condition", EKSAKTA: Berkala Ilmiah Bidang MIPA, 19(2), pp. 21-31. doi: 10.24036/eksakta/vol19-iss2/138.

Stefanie Amelia Dimpudus, Paulina V.Y Yamelan, Adhitya Yudistira, Formulasi sediaan sabun cair antiseptic ekstrak etanol bunga pacar 
air (inpatiens balsamina L) dan uji aktivitas terhadap bakteri staphyloccus aureus secara in vitro, FMIPA UNSRAT, Manado, p. 209.

Sukawati, Yullia, Warnida, Husul, dan Artha, Ananda Verranda, (2016), Formulasi sediaan sabun mandi padat ekstrak etanol umbi bawang tiwai (Eleutherine bulbosa (Mill.) Urb.). Akademi Farmasi.Samarinda, p. 2050.

Suryani A, Sailah I, Hambali E., 2000, Teknologi Emulsi, Institut Pertanian Bogor, Bogor, Hal.32

Syahrurahman A, Chatim A, Soebandrio A, Karuniawati A, Santoso A, Harun B, (2010), Buku Ajar Mikrobiologi
Kedokteran. Bina Rupa Aksara Publiser, Jakarta, hal 123.

Widyasanti, Asri, Chintya Listiarsi Farddani, Dadan R., 2016. Pembuatan Sabun Padat Transparan Menggunakan Minyak Kelapa Sawit (Palm Oil) dengan Penambahan Bahan Aktif Ekstrak The Putih (Camellia sinensis). Jurnal Teknik Pertanian Lampung Vol.5, No.3. Hal. 125-136.

Yernisa, E., and Khaswar Syamsu TIP, 2014, Aplikasi Pewarna Bubuk Alami dari Ekstrak Biji Pinang (Areca catechu L.) Pada Pewarnaan Sabun Transparan. Journal of Agroindustrial Technology 23.3. 